\title{
Religião, Estado, modernidade: notas a propósito de fatos provisórios
}

\author{
EMERSON GIUMBELLI
}

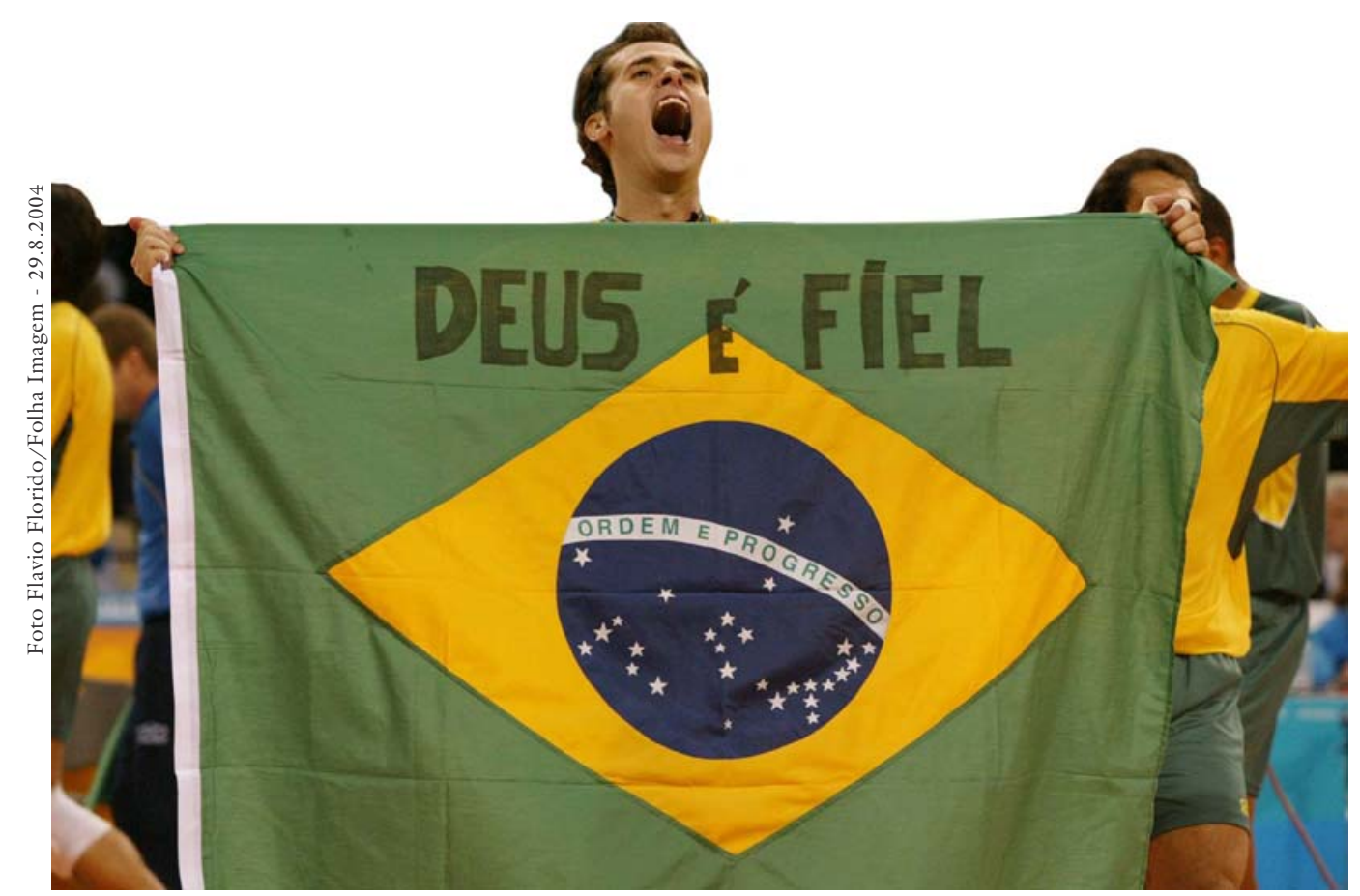

O levantador Ricardinho comemora a medalha de ouro da seleção masculina de vôlei em Atenas.

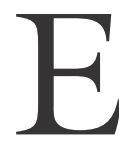

Ra dia de encerramento das Olimpíadas de Atenas, 2004. Ao final do jogo, que rendeu uma medalha de ouro à seleção brasileira de vôlei, assistimos pela televisão as imagens da comemoração. Em meio ao êxtase da vitória, um dos jogadores brasileiros, diante das câmeras, estendia a bandeira alterada por uma inscrição: "Deus é fiel". Tal expressão, que então se projetava para milhões de espectadores pelo mundo afora, é a mesma a que já nos acostumamos a ver em competições domésticas e que se tornou um dos inúmeros indícios de religiosidade pública - algo que se associa à expansão dos evangélicos nas últimas duas décadas no Brasil e ao seu impacto social e político. No mesmo dia, um dos destaques do noticiário acompanhava outro seqüestro de ocidentais por um grupo militante no Iraque. O episódio, dessa vez, envolvia dois jornalistas franceses. Os seqüestradores ameaçavam matá-los caso as autoridades francesas não revogassem a lei que pró́be o uso do véu muçulmano em escolas públicas. Hoje, a França abriga o maior contingente de muçulmanos na Europa Ocidental 
e lá o islamismo se converteu na segunda maior religião, atrás, em número de adeptos, apenas do catolicismo. A lei fora promulgada em março de 2004 e entraria em vigor no rei-nício das aulas, algumas semanas depois do dia de encerramento das Olimpíadas.

Mesmo com pouco esforço, poderíamos reunir uma série de outras evidências de referências ao "religioso" como dimensão significativa da atualidade. $\mathrm{O}$ acúmulo dessas evidências desenha um panorama que contrasta com a imagem que, por muito tempo - pelo menos desde o fim do século XVIII - se cultivou no Ocidente e que anunciava o "fim da religião". Parte dessa imagem está associada ao que podemos genericamente chamar de laicização do Estado. Isso implicava, em um plano mais estrito, a desvinculação entre aparato estatal e instituições religiosas; mas envolvia, de maneira mais extensa, um ideal de eliminação de toda referência a valores e a conteúdos religiosos nas áreas reguladas por leis civis, e por conseguinte, do próprio espaço público. Incluía-se aí a perda de relevância política para todas as identidades de base religiosa: ou seja, para o Estado tornava-se indiferente o fato de um cidadão se identificar como católico, protestante, judeu etc. ${ }^{1}$. É uma questão pertinente saber se houve uma mudança nos referenciais e ideais jurídicos; de todo modo, parecemos estar longe do horizonte que se associava ao modelo consolidado na modernidade, o horizonte do "fim da religião". Se muito se pode discutir acerca do estatuto e do significado do "religioso" atual, é difícil negar que a atualidade está repleta de "religião".

Não deixa de ser paradoxal que a mesma modernidade que exigiu a separação entre Estado e igrejas, governo civil e religião, também instituiu a "liberdade religiosa" e proclamou a isonomia de todos os coletivos de culto. Com isso, deixou-se aos indivíduos e aos grupos a tarefa de elaborar e se pronunciar sobre questões fundamentais da existência, embora a própria modernidade tenha desenvolvido outros espaços para tratar das mesmas questões. Cabe ainda lembrar que essa "liberdade" atribuída à "religião" foi concebida como algo relativo. Afinal, a "religião" estaria circunscrita a um domínio definido em relação a outros domínios e a liberdade só valeria se não deixasse de respeitar essas fronteiras sociais. Além disso, na modernidade, tornou-se crucial o contraponto "religião" e "ciência", sem esquecer que enquanto se associa a primeira com "crenças", se espera que a segunda produza "verdades". E se muitas vezes se viu na "religião" a fonte de uma moralidade socialmente útil, foi para nela encontrar um apoio e um sustento para uma ordem cujos fundamentos estavam em outro lugar. Ou seja, mesmo a "liberdade religiosa" deriva de um ideal capaz de conceber a sociedade sem religião. É isso que torna inerentemente ambígua a convivência entre modernidade e religião.

As evidências de que a religião se tornou incontornável na atualidade não estão apenas nos noticiários, mas também em debates que colocam em questão as relações entre Estado, religião e sociedade. Proponho que acompanhemos dois desses debates, notando como neles a modernidade, por um lado, aparece como referencial crucial e, por outro, é transtornada pela importância que se 
concede à religião. Ao acompanhá-los, retomaremos os contextos nacionais mencionados logo no início do texto, ou seja, França e Brasil. Escolhi alguns textos e documentos que representam intervenções nesses debates, fragmentos de conjuntos mais amplos. Caso estivesse analisando esses conjuntos em sua exten-são, não defenderia a possibilidade de isolar aqueles textos e documentos. Todavia, creio ser possível dar uma contribuição para a análise dos próprios debates a partir de alguns de seus fragmentos. Embora os textos e documentos escolhidos não sejam "representativos", destacam-se por guardarem, de algum modo, um vínculo direto com o Estado. Interferem em dimensões legais ou partem de autores envolvidos com iniciativas governamentais. Além disso, deve-se considerar que se tratam de elaborações recentes, e são a prova de que o objeto de sua intervenção está ele mesmo em construção. A provisoriedade é um elemento essencial dessas situações e do que se pode, sob qualquer ponto de vista, dizer sobre elas.

Comecemos pela França. O documento que escolhi é o relatório da Comissão sobre a Laicidade criada pela Presidência da República. Formada por vinte membros, funcionários, militantes, intelectuais de diversas especialidades (incluindo pensadores do porte de Alain Touraine e Gilles Kepel), a comissão funcionou entre julho e dezembro de 2003. Nesse período, promoveu uma centena de audiências abertas e algumas dezenas de audiências fechadas. Foram ouvidos "representantes políticos, religiosos, sindicais, administrativos, associativos", além de "vereadores, diretores de empresas, diretores de escolas, professores, diretores de hospitais e de prisões, enfermeiras". Fizeram ainda parte das atividades da comissão um debate público com alunos de liceus, o exame de contribuições escritas e uma missão de viagem que alcançou outros países europeus. À comissão foi solicitado um conjunto de medidas que servissem para orientar o Poder Executivo. O relatório foi oficialmente entregue em dezembro de 2003 e é esse texto, que teve repercussões e conseqüências importantes, que será analisado a seguir ${ }^{2}$.

Pode-se perceber no relatório da Comissão sobre a Laicidade a configuração de um diagnóstico sobre a realidade atual levando em conta a presença da religião e seu tratamento na sociedade francesa. Três pontos compõem esse diagnóstico. Primeiro, a constatação do pluralismo do campo religioso e espiritual. Sem perder de vista a relação privilegiada com o catolicismo, a importância do protestantismo e do judaísmo é admitida; a presença inexorável do islamismo é ressaltada; são ainda citados o cristianismo ortodoxo e o budismo, bem como os "ateus, agnósticos e livres pensadores". O segundo ponto é o reconhecimento de uma desigualdade no modo como essas diferentes expressões religiosas e espirituais estão presentes na sociedade francesa. Nesse caso, a ênfase recai sobre o islamismo, geralmente desfavorecido pela insuficiência de lugares de culto, pelo não reconhecimento oficial de seus feriados, pela carência no atendimento de suas especificidades rituais em escolas, hospitais, prisões, quartéis, em refeitórios coletivos e cemitérios públicos - e ainda pela desvantagem social e cultural das 
populações de origem muçulmana que formam a maior parte dos seus adeptos. Por fim, há no relatório uma denúncia do "comunitarismo", termo que pretende designar dinâmicas sociais que exacerbam a identidade cultural. É o que aconteceria entre as populações desfavorecidas, entre as quais se encontrariam exemplos de uma reação que implica colocar as "tradições" acima dos indivíduos. O "comunitarismo" é visto como um perigo e duas definições resumem o ideal a ser buscado contra o problema a ser enfrentado: a coexistência e a convivência "em um mesmo território de indivíduos que não compartilham as mesmas convicções" versus a justaposição de "um mosaico de comunidades fechadas sobre elas mesmas e mutuamente exclusivas".

Para chegarmos às propostas da comissão, devemos discutir o entendimento da "laicidade", tema geral do relatório. A laicidade, concebida como um valor comum necessário, passa por outros três princípios. Uma postura semelhante em relação à religião se verifica nesses três princípios, na medida em que funcionam ao mesmo tempo para garanti-la e limitá-la. Comecemos pelo princípio da separação, que o relatório se recusa a reduzir à exigência de neutralidade do Estado. Se a separação assegura que as opções espirituais ou religiosas não envolvam o Estado e que este não se envolva com aquelas, ela demanda também que o Estado cuide das condições de possibilidade da expressão religiosa, assim como postula a renúncia, por parte das religiões, à sua dimensão política. A laicidade pede a cada uma das religiões um esforço de adaptação e de conciliação de seus dogmas com as leis que regem a sociedade. Outro princípio é o da igualdade, que comanda um tratamento isonômico por parte do Estado, mas exige das religiões que não façam demandas particularistas. Por exemplo, no serviço público, nega-se firmemente a possibilidade de recusa de atendimento ou de subordinação por razões religiosas. E o terceiro princípio é o da liberdade de consciência. Ao mesmo tempo em que a laicidade afirma a "liberdade de consciência", impõe como limitação as exigências da "ordem pública" - por exemplo, as condições necessárias para o funcionamento normal de uma instituição. De modo semelhante, se é a liberdade de consciência que funda o direito à livre expressão religiosa no espaço e no debate públicos, é ela também que impele o Estado a proteger o indivíduo contra toda imposição religiosa.

Entender o composto que constitui tanto o diagnóstico da situação religiosa quanto o entendimento da laicidade ajuda a perceber os sentidos também diversos das recomendações feitas em nome da comissão. Um dos vetores procura reforçar a neutralidade do Estado, especialmente nas regras aplicadas aos servidores e serviços públicos. Nesse sentido, insiste-se que os servidores devem exercer suas funções colocando em suspensão suas opiniões pessoais, políticas e filosóficas, inclusive as religiosas. A mesma medida, no entanto, pode ser interpretada como aplicação da exigência de ordem pública, exigência que vai limitar o espaço de expressão da religião, deixando o funcionamento de instituições públicas imunes às suas influências e demandas. Por outro lado, medidas diversas 
colocam o Estado como um fator direto de intervenção no campo religioso. Entre elas estão a criação de uma "escola nacional de estudos islâmicos", a habilitação de capelães muçulmanos em instituições coletivas em regime de internato, a adequação de estabelecimentos públicos para atender exigências religiosas em matéria de alimentação e rituais funerários, a inclusão de mais dois feriados no calendário nacional (correspondentes a datas sagradas no judaísmo e no islamismo).

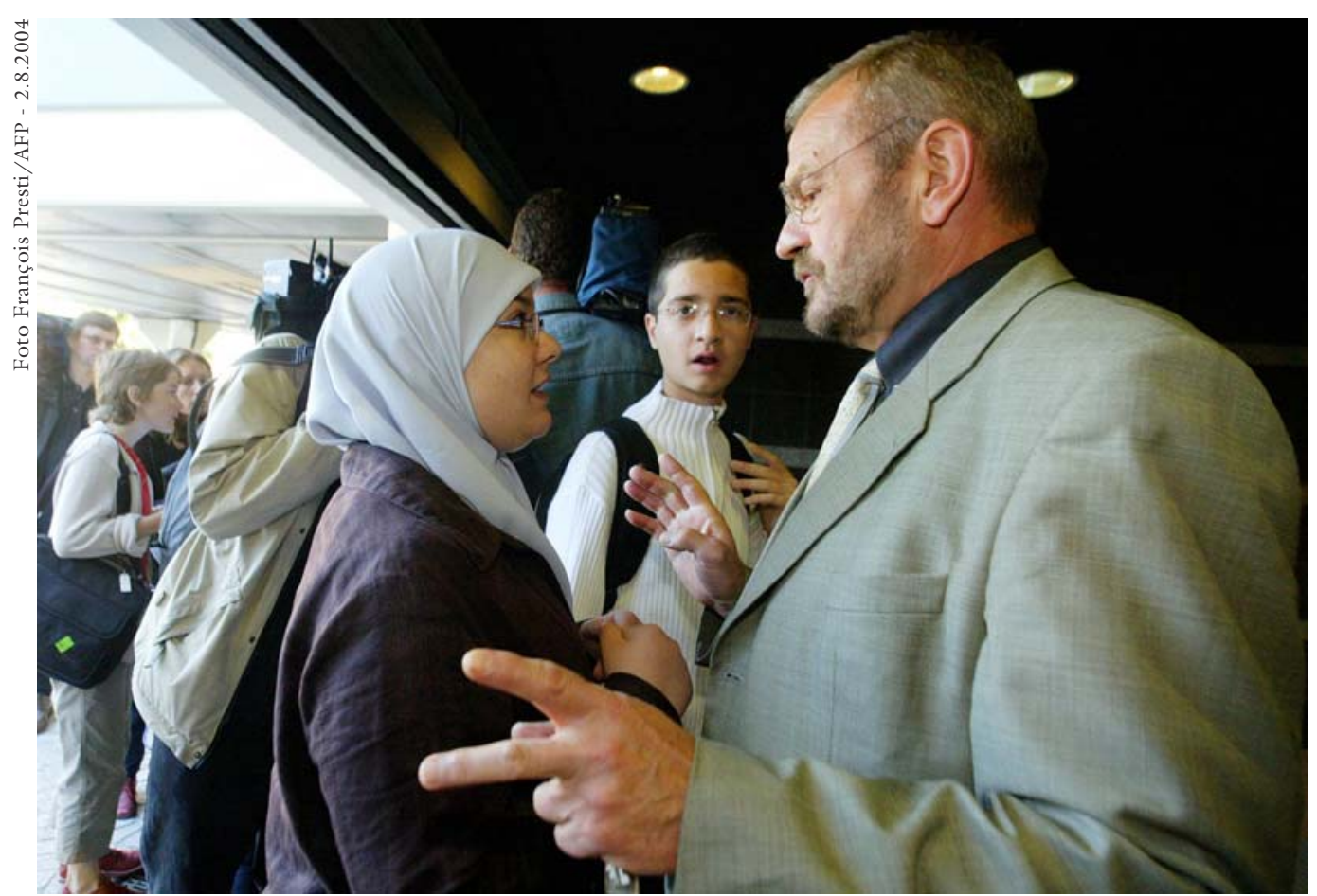

Segurança proíbe entrada de estudante no liceu Queneau, em Villeneuve-d'Asq, no norte da França.

Um campo interessante para perceber como se faz presente essa diversidade na maneira de considerar a religião é a escola. Embora o relatório preocupe-se com vários tipos de instituições na sua relação com a laicidade, é certamente a escola o foco principal. E pour cause. De fato, a escola desempenha no debate relativo à laicidade na França um papel fundamental. No final do século XIX, a propósito do ensino religioso, que foi suprimido durante a III República. Ao longo do século XX, por conta da relação do Estado com as escolas particulares, em sua grande maioria católicas. E desde 1989, em consideração a inúmeros episódios suscitados pelo uso do véu por alunas muçulmanas em escolas públicas. No segundo semestre de 2003, a sociedade francesa estava mais uma vez mobilizada em torno da questão do véu. Em outubro, duas irmãs foram expulsas de uma escola pública depois que se recusaram a retirar o véu. Ao contrário da maioria dos casos, as irmãs vinham de uma família não muçulmana. Em dezembro, conclui seu relatório a Missão de Informação sobre a Questão dos Signos Religiosos na Escola, grupo criado no âmbito da Assembléia Nacional. A demanda vinda dos funcionários escolares por uma orientação unificada por parte do Estado era evidente ${ }^{3}$. 
A Comissão sobre a Laicidade fez sua recomendação mais categórica a propósito exatamente dessa questão. Embora reconhecendo que a liberdade de consciência estava em jogo, a comissão tomou o partido da ordem pública. Na sua avaliação, o desenrolar normal das atividades escolares vem sendo prejudicado pelas tensões e conflitos a propósito de questões religiosas. Além disso, parece considerar que o véu não é apenas um símbolo religioso, mas o indício da dominação da família e dos grupos comunitários sobre os indivíduos, dos homens sobre as mulheres. E, afirma o relatório, “o espaço escolar deve permanecer para elas [as alunas] um lugar de liberdade e de emancipação". Com base nisso, a comissão propôs que fosse elaborada uma lei que proíba nas escolas públicas “os trajes e signos manifestando um pertencimento religioso ou político". Essa recomendação foi prontamente acolhida pela Presidência da República, que algumas semanas depois enviou um projeto de lei à Assembléia com base no relatório da Comissão sobre a Laicidade. As discussões no parlamento não trouxeram alterações significativas e a lei que modificou o Código da Educação foi promulgada em março de 2004 com o seguinte texto: “[nas escolas públicas], o porte de signos e trajes pelos quais os alunos manifestam ostensivamente um pertencimento religioso é interdito". Foi essa lei - que passaria a valer no reinício das aulas em setembro, gerando enorme expectativa - que teve sua revogação exigida pelos seqüestradores dos jornalistas franceses no Iraque.

Um outro tema na relação entre escola e religião aparece ainda no relatório da Comissão sobre a Laicidade. É o do ensino da religião na escola pública. Se o debate sobre o véu movimenta os temores vindos - para usar uma expressão do relatório - de "instrumentalizações político-religiosas", o debate sobre o ensino da religião radica-se na constatação de "incultura religiosa" que acometeria os jovens franceses ${ }^{4}$. A comissão posiciona-se sobre o assunto: "Uma melhor compreensão mútua das diferentes culturas e tradições de pensamento religiosas é hoje necessária. [...] A ocasião de afirmar uma laicidade ativa, desenvolvendo o conhecimento raciocinado e a abordagem crítica dos textos [sagrados], deve ser aproveitada". Nesse sentido, o texto elogia modificações curriculares recentes que introduziram temas religiosos nas disciplinas de francês e de história e recomenda que o "ensino do fato religioso" seja incluído na formação de professores. Além disso, sugere que na região da Alsácia-Moselle - onde não vigora a lei de separação entre Estado e Igrejas e o ensino religioso é oferecido em caráter confessional e facultativo nas escolas públicas - o islamismo seja também contemplado.

Procurei mostrar como os diagnósticos da situação religiosa, os entendimentos da laicidade e as recomendações concretas presentes no documento produzido por uma comissão oficial do governo francês não seguem uma linha única. Oscilam entre os referenciais modernos de restrição do religioso e o reconhecimento da sua incontornabilidade atual. Sugere-se, ao mesmo tempo, que a religião esteja fora (como "signo") e dentro (como "fato" a ser estudado) da es- 
cola. O fato de que essas elaborações se façam em torno da noção de laicidade noção que literalmente implica uma oposição ao religioso - deve ser tomado como um poderoso signo de que entre modernidade e religião existem relações positivas. Para mostrar que recusa e reconhecimento podem vir juntos, basta seguir mais um pouco o episódio do seqüestro dos jornalistas franceses. Pois uma das providências tomadas pelo governo francês foi o envio ao Iraque, visando à negociação com os seqüestradores que pediam a revogação da "lei contra o véu”, de uma missão composta por autoridades e lideranças islâmicas francesas...

Passemos ao Brasil para acompanhar algumas peças do debate que também aqui ocorre sobre ensino da religião na escola pública. O tema sempre foi matéria constitucional na história republicana de nosso país. Negado pela Constituição de 1891, o ensino religioso foi incluído na seguinte, a de 1934, e nunca mais foi suprimido. A Constituição de 1988 estipula em seu artigo 210, parágrafo $1^{\circ}$ : "O ensino religioso, de matrícula facultativa, constituirá disciplina dos horários normais das escolas públicas de ensino fundamental". Historicamente, o ensino religioso esteve ligado aos interesses e à influência da Igreja Católica na sociedade brasileira. Outras tradições religiosas, quando não se opuseram, não se envolveram na questão. Na elaboração de Constituição de 1988, organizações e intelectuais ligados ao setor educacional combateram a continuidade do ensino religioso. A Lei de Diretrizes e Bases, promulgada em 1996, definia que o ensino religioso não seria custeado pelos cofres públicos. Uma lei do ano seguinte mudou essa situação, ao mesmo tempo em que vedou "quaisquer formas de proselitismo" (Lei 9475/97). Paralelamente, o Conselho Federal de Educação tomou resoluções no sentido de transferir para as unidades da federação a regulamentação da disciplina ${ }^{5}$.

No Estado do Rio de Janeiro, um projeto de lei foi apresentado em 1999 pelo deputado Carlos Dias, com o apoio da Arquidiocese local. Com algumas modificações, o texto tornou-se a Lei $3459 / 00$, promulgada pelo governador Anthony Garotinho em 2000. Nela, embora se vede o "proselitismo", fica estabelecido que o ensino religioso será oferecido "na forma confessional" - nesse modelo, os alunos que se dispõem a freqüentar a disciplina devem ter professores e conteúdos próprios a cada confissão. Quanto aos professores, além do registro no MEC, estipula-se que devem ser "credenciados pela autoridade religiosa competente". E quanto ao currículo, "fica estabelecido que o conteúdo do ensino religioso é atribuição específica das diversas autoridades religiosas, cabendo ao Estado o dever de apoiá-lo integralmente". Com base nessa lei, foram realizadas, em janeiro de 2004, as provas de um concurso para professores de ensino religioso na rede estadual de educação. Exigia-se dos candidatos formação universitária com Licenciatura Plena. As quinhentas vagas foram divididas em três categorias: “católicos” (342 postos), “evangélicos” (132) e “outros” (26). O que definia o pertencimento religioso do candidato era um "credenciamento" expedido por uma "autoridade religiosa". Esses quinhentos novos professores 
de ensino religioso, quase todos efetivados ao longo de 2004, vieram se juntar aos poucos mais de duzentos que existiam anteriormente.

As definições legais que sustentam esse modelo foram objeto de várias reações, dentro da Assembléia Legislativa, na Justiça e na imprensa. Na polêmica, um nome que se destacou foi o do deputado Carlos Minc. Já nas primeiras discussões do projeto de Carlos Dias, Minc apresentou emendas; após a promulgação da Lei 3459/00, Minc juntou-se a outros parlamentares e propôs outro projeto de lei, finalmente aprovado em 2003 pela Assembléia Legislativa (PL 1840/2000). Nele, atribui-se ao Sistema Estadual de Ensino tanto a definição dos conteúdos curriculares, "ouvida entidade civil constituída pelas diferentes denominações religiosas", quanto o estabelecimento das normas para a habilitação, a admissão e a capacitação dos professores. O texto, no entanto, foi vetado por Rosinha Garotinho e definitivamente arquivado em março de 2004 depois de a Assembléia Legislativa ter se resignado à decisão da governadora. À mesma época, Rosinha Garotinho declarou em uma entrevista ser pessoalmente favorável às teses criacionistas.

As razões apresentadas pela governadora para vetar o projeto elaborado pelo grupo encabeçado por Carlos Minc formam o primeiro dos documentos que pretendo analisar ${ }^{6}$. O texto aponta que haveria "vício de iniciativa" na determinação pelo Legislativo de atribuições ao Executivo. Menciona que a Lei 3459/ 00 já foi regulamentada pelo Poder Executivo e que um concurso público já estava acontecendo para prover as vagas para os professores. Na sua última parte, o texto busca precisar os objetivos do ensino religioso, referindo-se à "crise de valores do momento presente". Segundo a governadora, ele daria "a oportunidade de uma completa formação e integral educação dos alunos”, pelo ensino dos "pilares da ética, da moral, do amor ao próximo e da solidariedade”. Enfim, "[é] o caminho da coerência entre a fé e a vida, com a preparação do coração dos nossos jovens para que se tornem conscientes de seu papel de agentes responsáveis para com a cidadania e a realização do ideário de justa sociedade". O texto reafirma que a "diversidade cultural religiosa" será respeitada, sob a forma confessional, que separa conteúdos, professores e alunos. Mas, como se vê, o objetivo é um só: responder a uma "crise de valores" com uma "formação" que junta "moral" e "cidadania".

Em 2000, algumas semanas depois que a Lei 3459/00 foi promulgada, o deputado Carlos Minc teve um artigo publicado no jornal $O G l o b o^{7}$. Nele expõe argumentos que podemos pôr em diálogo com os da governadora. Minc assente que a "dimensão espiritual" seja importante: "Hoje, nas favelas e nas prisões, a religião é um dos poucos contrapontos ao poder do tráfico”. No entanto, vai questionar o modelo confessional utilizando-se de um discurso resolutamente moderno: "O cerne da questão não é pôr em causa se o conhecimento da teologia e da filosofia das religiões é necessário ou se os valores espirituais ajudam a formação mais ampla das consciências. $\mathrm{O}$ âmago da questão é a relação constitu- 
cional entre a Igreja e o Estado". Nesse caso, segundo Minc, vivemos sob um paradigma que consagra a separação entre essas duas instâncias. A Lei 3459, continua ele, perverte essa separação ao atribuir a autoridades religiosas poderes sobre o currículo de escolas públicas e sobre os funcionários também públicos. Um ensino confessional, sob a tutela de autoridades religiosas, só pode existir custeado pelos fiéis de cada confissão e dentro de seus espaços de culto. Já o ensino religioso prometido pela Constituição Federal e pela LDB deve ser definido pelo Estado, que contratará professores sem ingerência religiosa. Quanto aos currículos, o Estado deverá consultar "o conjunto das comunidades religiosas", no sentido de configurar "uma disciplina de caráter inter-religioso"

Mudemos de Estado e nos transportemos para São Paulo. Não estou a par das definições legislativas nesse Estado. De todo modo, os textos que irei analisar vinculam-se a iniciativas que se deram no âmbito do Poder Executivo. $\mathrm{O}$ primeiro deles deriva de uma parceria estabelecida entre a Secretaria de Educação e a Universidade Estadual de Campinas a partir de diretrizes definidas pelo Conselho Estadual de Educação em setembro de 2001. A parceria resultou na produção de material de apoio didático e em atividades de capacitação dirigidas aos professores. Visou-se especificamente aos alunos da $8^{a}$. série. A equipe responsável pela elaboração do material pertence ao Departamento de Pós-Graduação em História da Unicamp. O segundo texto remete à participação de sua autora em uma iniciativa anterior, também do governo do Estado, que em 1995 criou uma Comissão Especial sobre Ensino Religioso em Escolas Públicas. A comissão redigiu um relatório que foi apresentado ao então governador Mário Covas e à Secretaria de Educação. Passo então a apresentar esses dois textos, insistindo na possibilidade de termos um diálogo não só entre eles, mas também com os textos produzidos a propósito da situação do ensino religioso no Rio de Janeiro.

O primeiro texto procura apresentar a proposta que embasa o material elaborado pela equipe da Unicamp, na qual as autoras estiveram integradas. Viana, Bellotti e Bassini (s/d) partem do princípio de que, sendo o Estado laico, a escola pública constitui um espaço de conhecimento e convivência, independentemente da religião de cada um. Nesse âmbito, o ensino religioso deve ser assumido por professores que já possuam habilitação em História, Filosofia ou Ciências Sociais. A abordagem, em termos mais estritos, procura oferecer uma visão sobre o "fenômeno religioso" considerado na sua pluralidade e no vínculo indissociável entre textos e práticas. As religiões devem ser apresentadas como parte de um patrimônio cultural histórico coletivo e como constitutivas das identidades pessoais. Mas a proposta guarda ainda uma ambição maior: discutir "valores" e "princípios éticos", estimulando-se a "tolerância ativa" e a "compreensão do 'outro"”. Através do "conhecimento da religião do outro" (e sem partir do pressuposto de que "todas as religiões são boas"), pretende-se "compreender a existência de pontos comuns éticos e de convivência em grupo nas mais diferentes culturas". 
O segundo texto, embora publicado recentemente, foi escrito por R. Fischmann (2004), que participou como representante da USP da comissão de 1995. Anuncia que sua posição parte da consideração do "direito à educação e suas inter-relações com o direito à liberdade de crença [também de consciência e de culto] num Estado laico, como é o Brasil". O texto, portanto, alinha-se a um discurso moderno, como também o demonstra a insistência sobre a distinção entre a ciência - orientada pelo tangível, protegida do dogmatismo e marcada pela universalidade - e a religião - presa ao intangível, suscetível à manipulação das consciências, assunto de foro íntimo. Isso não significa que a autora não reconheça a importância da religião: afinal, ela pode ser uma fonte relevante e legítima de decisão pessoal, mesmo um "referencial de vida". Mas sua natureza essencialmente subjetiva e a laicidade do Estado desaconselham a sua presença na escola. Àqueles que propõem um ensino inter-religioso, Fischmann retruca: como encontrar "denominador comum" e como evitar que se considere como detalhes o que é importante dentro de crenças específicas? Por outro lado, se direitos humanos e ética são conteúdos que podem e devem integrar o projeto político-pedagógico da escola, nada obriga que o sejam através do ensino religioso. Enfim, a família e a religião seriam os agentes apropriados para a transmissão dos conteúdos religiosos à criança, de forma confessional, na sua diversidade e pluralidade.

Vislumbremos o quadro da discussão sobre o ensino religioso em escolas públicas no Brasil formado pelos quatro fragmentos escolhidos. Embora muitos pontos merecessem comentários, privilegio os significados de duas categorias, que servem a um só tempo para localizar focos comuns e para apontar a diversidade com que são compreendidos. Pois, de fato, em nenhuma das posições apresentadas se observa uma recusa da noção de laicidade e em todas elas se coloca uma ênfase sobre o pluralismo. E apesar disso, temos quatro modelos distintos para pensar a relação entre Estado, escola e religião. No primeiro deles, o argumento implícito é de que mesmo o Estado laico não pode se desinteressar pela dimensão que da melhor forma transmite as noções de "cidadania" e de "moral”; posta esta necessidade, é exatamente o modelo confessional que preserva a pluralidade das opções religiosas. No segundo, esse modelo confessional é negado em nome da laicidade e o pluralismo seria contemplado através de uma entidade consultiva formada pelas diferentes denominações religiosas. No terceiro, os representantes religiosos são contornados por uma proposta baseada em um saber acadêmico capaz de despertar para os valores da boa convivência e o pluralismo seria contemplado por meio de uma abordagem que se recusa a considerar as expressões religiosas como derivações de uma essência única. No quarto, laicidade e pluralismo articulam-se para desaconselhar a presença da religião na escola, espaço aberto de aprendizado da ciência e de formação da consciência.

A existência de pontos de encontro em meio à produção de modelos tão diferentes faz pensar sobre os caminhos da modernidade no Brasil - e acredito 
que as relações entre Estado, sociedade e religião oferecem um campo precioso para isso. Talvez a França seja o país que viva mais fortemente ao paradoxo da separação contida na noção de laicidade: separar implica distinguir, e distinguir implica definir os termos produzidos na relação. Assim, não há nada de casual que a mesma lei que consolida a separação entre Estado e igrejas tenha se dedicado à criação da "associação de culto", uma figura jurídica nova para abrigar as instituições especificamente religiosas. No Brasil, houve a separação entre Estado e Igreja, mas sem a contrapartida da definição desse espaço propriamente religioso. Até hoje, em termos jurídicos e com exceção de algumas regras fiscais, não há característica ou exigência que distinga as instituições religiosas de outras “associações sem fins lucrativos". O resultado é a articulação entre um Estado "moderno" - juridicamente laico - e uma sociedade "tradicional" - que não necessita se organizar de modo a manter o religioso dentro de limites próprios e específicos. O debate recente sobre o ensino religioso na escola pública, na medida em que produz modelos bem distintos em torno das noções modernas de laicidade e de pluralismo, parece confirmar a possibilidade dessa articulação.

Mas, em se tratando de ensino da religião na escola pública, voltemos um momento ainda à França. Pois especificamente sobre esse assunto um outro relatório foi produzido por solicitação do Ministério da Educação. Concluído em fevereiro de 2002, quem responde pela autoria é o famoso escritor Régis Debray, que também participou da Comissão sobre a Laicidade de 2003. O Relatório Debray (2002) posiciona-se a favor do ensino da religião nas escolas públicas e sugere, como o relatório da Comissão sobre a Laicidade, o aprofundamento das modificações inseridas em programas de história e de francês. Mas que modelo Debray defende? Trata-se do "ensino do religioso" e não de "ensino religioso", ou seja, "uma abordagem descritiva, factual e nocional das religiões presentes, na sua pluralidade, do Extremo Oriente ao Ocidente, e sem procurar privilegiar uma ou outra". Debray confia na capacidade dos professores de suspender suas conviç̧ões pessoais e aposta nos resultados de um programa de formação e capacitação. Que professores? Seriam professores de letras e línguas, de filosofia, de artes, de história e de geografia. Ou seja, não deveria haver uma disciplina específica para o “ensino do religioso". Não só por razões pragmáticas (sobrecarga dos horários), mas também para evitar perversões do modelo (chance de religiosos se tornarem professores). Além disso, Debray se nega a atribuir à religião "o monopólio do sentido" (afinal, existem "respostas profanas" às "questões religiosas") e vê as religiões como parte indissociável das humanidades e como caminho para reforçar o seu conhecimento ( "como, pergunta, retraçar a aventura irreversível das civilizações sem levar em conta as pistas deixadas pelas grandes religiões?”).

Esse modelo defendido por Debray e pela Comissão sobre a Laicidade - e já implantado, ao menos parcialmente - opta, portanto, por um enfoque "distanciado" e "transversal" da religião como parte dos currículos escolares. A preocupação com o "viver conjunto" e com a transmissão de referências comuns 
está presente em ambos os textos apresentados ao governo francês. Pode-se estabelecer, nesse caso, uma relação com a ênfase do Relatório Debray na "abordagem das religiões como fatos de civilização". "Civilização" teria aí também um sentido literal. Ou seja, por oposição a um mundo "barbarizante", que valoriza o efêmero e que retira o sentido da profundidade, o estudo do religioso seria uma maneira de "civilizar" os jovens. Em direção semelhante, Debray considera que o ensino do religioso teria uma dimensão "preventiva”. Aos que recusam esse ensino, o escritor retruca: "A relegação do fato religioso para fora das muralhas da transmissão racional e publicamente controlada dos conhecimentos favorece a patologia do terreno em vez de saneá-la". O "ensino do religioso" seria uma forma inteligente de se defender da“"onda esotérica e irracionalista", dos "integrismos", dos "charlatães", das "paixões sectárias".

Se o grande vilão do relatório da Comissão sobre a Laicidade é o "comunitarismo", esse papel no Relatório Debray é desempenhado pelo "analfabetismo religioso". Curiosamente, o escopo de "problemas" cobertos por essas expressões é maior no último caso. Pois o "analfabetismo" estaria associado ao "integrismo", algo que se define pela perversão dos limites entre o religioso e o político e, portanto, fere a concepção que se espera de uma sociedade que tem na laicidade um valor comum. Mas também estaria associado com os "charlatães" e as "paixões sectárias". Ora, ao lado do islã, as "seitas" constituem o outro grande "problema" no debate sobre Estado, religião e sociedade na França das últimas décadas 9 . O surpreendente silêncio total do relatório da Comissão sobre a Laicidade acerca da questão das "seitas" é significativo. Reforça a tendência dominante no debate, que se baseia exatamente no argumento de que as "seitas" não são "religiões". Já o Relatório Debray, ao mencioná-la, evidencia a finalidade profilática do "ensino do religioso" em relação às "seitas". E uma frase sua permite fazer a conexão com o tema maior: "Parece chegado o tempo da passagem de uma laicidade de incompetência (o religioso, por construção, não nos interessa) a uma laicidade de inteligência (é nosso dever compreendê-lo)". Podese discutir se houve, em algum momento da história da França laica, "desinteresse" sobre a religião. De todo modo, a provocação de Debray - assim como toda a controvérsia sobre as "seitas" - demonstra que "laicidade" e necessidade de definição do "religioso" andam juntas na França.

Os temas do "viver conjunto" e da "civilização" assumem, nos textos apresentados no Brasil, a referência a dimensões e designações variadas - "moral", "ética", "valores", "tolerância", "cidadania". Em nosso caso, no entanto, o problema para o qual se procura uma resposta não é o do "analfabetismo religioso". Ao contrário, partimos de um certo consenso sobre a pujança da religiosidade entre os brasileiros e nosso dilema passa a ser como lidar com essa condição considerando o espaço e as finalidades da instituição escolar. Por outro lado, os tropos da "barbárie" e do dilaceramento social remetem a questões bastante agudas, como um cotidiano recortado por rituais de desigualdade e por uma 
violência crônica. Trata-se de um quadro que reconfigura a discussão sobre as exigências da laicidade, muito embora isso nem sempre seja reconhecido ou explicitado em debates pautados mais por princípios do que por condições concretas. Ao mesmo tempo, dado que desigualdade e violência se reproduzem em conexão com as dimensões mais "civilizadas" dessa sociedade, elas se tornam também as marcas de nossa "modernidade".

Os quatro textos aqui comentados podem ser organizados segundo uma gradação da ruptura que demandam em relação ao sistema vigente. Assim, dentro desse critério, o texto de Fischmann ocuparia um dos extremos, aquele que identifica o maior grau de ruptura. Ao menos, na medida em que implicaria uma modificação constitucional, no sentido de suprimir a exigência de oferta de ensino religioso. Em uma posição intermediária, teríamos a proposta apresentada pela equipe da Unicamp e o modelo defendido pelo deputado Carlos Minc. Ambos apostam na possibilidade de se chegar a um programa disciplinar único, que envolve, no primeiro caso, a intervenção do saber acadêmico e, no segundo, a constituição de uma entidade interconfessional. Lembremos que a primeira proposta já teve sua implementação iniciada, no próprio Estado de São Paulo. Outros Estados, como o de Santa Catarina, investiram na criação de um "conselho" de representantes religiosos. No outro extremo de nossas opções, temos o modelo instaurado no Rio de Janeiro, com o apoio do atual governo - nele, as próprias estruturas institucionais religiosas, cuja existência está suposta, são encarregadas de formar e avalizar os professores de ensino religioso contratados e sustentados pelo Estado.

No entanto, uma abordagem mais pragmática manteria esse quadro sujeito a reavaliações. Para demonstrá-lo, basta pensar apenas nos seus extremos. Uma proposta de mudança constitucional só representa uma ruptura real caso se torne socialmente plausível e sustentável. Além disso, em havendo chances de termos um movimento nessa direção, por que não incluir no debate o modelo não disciplinar de "ensino do religioso" francês? Por outro lado, se o modelo instaurado no Rio de Janeiro é o que representa o maior grau de continuidade com práticas anteriores, dois pontos devem ser observados. Entre as religiões, o modelo confessional tem seu maior propulsor na Igreja Católica. Ao fazê-lo, no entanto, não se trata apenas de dar continuidade ao passado, mas de procurar garantir um espaço de intervenção na sociedade (que toca na socialização de crianças e jovens) em um momento em que essa presença se vê ameaçada por outras referências, inclusive religiosas. Isso nos leva aos evangélicos. Mesmo como minoria, o "credo evangélico" teve providenciado seu acesso ao espaço escolar, algo historicamente inédito. Assim, tanto a postura da Igreja Católica, quanto a chance aberta aos evangélicos, sinalizam mudanças importantes, mesmo que elas estejam atreladas a um modelo "conservador" de ensino religioso.

Enfim, o campo é rico e complexo. Envolve questões sérias, que tocam seja em definições sobre o Estado e o público, seja no cotidiano de crianças e 
adolescentes que freqüentam as escolas. Nada está consumado e os dilemas são e serão muitos. No plano que implica definições legais, alguns modelos já foram estabelecidos e a variedade entre as unidades da federação deveria constituir um estímulo para a discussão e o acompanhamento da situação do ensino religioso. O Rio de Janeiro mostra que, mesmo com leis já regulamentadas e implementadas, o debate na sociedade continua e existem alternativas colocadas. Ao mesmo tempo, há todo um trabalho de pesquisa a ser feito junto às escolas. Afinal, é lá que se concretizam, ou não, os modelos definidos por providências legislativas e executivas. E se sabemos muitas coisas sobre as definições legais acerca da relação entre escola e religião ao longo da história brasileira, quase nada conhecemos sobre as condições concretas, no passado e no presente, do ensino religioso em cada uma das escolas ${ }^{10}$. Acompanhar debates sociais e condições concretas em torno do ensino religioso nos ajudará a saber de que modo, e se, no Brasil se é "fiel a Deus".

Notas

1 Sigo, nessa caracterização das implicações jurídicas da laicidade, as observações de Ferrari (1988). Para uma discussão mais ampla sobre as relações entre religião e modernidade, ver Giumbelli (2002).

$2 \mathrm{O}$ texto foi publicado pelo jornal Le Monde, em sua edição de 12 de dezembro de 2003 , pp. 17 a 24 . É dessa versão que me sirvo para fazer meus comentários.

3 Sobre os vários momentos do debate sobre a laicidade na sociedade francesa, ver, entre outros, Baubérot (1990), Bedouelle e Costa (1998), Poulat (1987), Ozouf (1982), Vários autores (1990), Hervieu-Léger (1999). Ver ainda, acerca da polêmica sobre o véu, o Dossiers \& Documents do Le Monde, n. 325, nov. 2003.

4 Em se tratando do debate francês sobre o ensino da religião das escolas públicas, uma referência útil é Boespflug, Dunand e Willaime (1996).

5 Para referências gerais sobre o ensino religioso no Brasil, ver Junqueira (2002).

6 "Razões do veto total ao PL 1840/00", documento consultado na seção de arquivos da Assembléia Legislativa do Estado do Rio de Janeiro.

7 O Globo, 9/10/2000.

8 A última expressão não foi retirada, como as demais, do artigo publicado no jornal, mas das justificativas (elaboradas na mesma época do artigo) anexas à apresentação do projeto de lei que se contrapunha à lei 3459. Este documento foi consultado na seção de arquivos da Assembléia Legislativa do Estado do Rio de Janeiro.

9 É esse exatamente um dos temas de minha tese de doutorado (Giumbelli, 2002).

10 Neste momento, com o apoio de recursos da Fundação Universitária José Bonifácio, conduzo uma pesquisa sobre a situação do ensino religioso no Rio de Janeiro. $\mathrm{O}$ objetivo é exatamente cobrir as várias posições emitidas no âmbito do Estado e da sociedade e acompanhar a situação concreta em algumas escolas. 
Bibliografia

BAUBÉROT, Jean. Vers un Noveau Pacte Laïque? Paris, Seuil, 1990.

BEDOUELLE, Guy e COSTA, Jean-Paul. Les Laïcités à la Française. Paris, PUF, 1998.

BOESPFLUG, François; DUNAND, Fraçoise e WILLAIME, Jean-Paul. Pour une mémoire des religions. Paris, La Découverte, 1996.

DEBRAY, Régis. L'Enseignement du fait religieux dans l'école publique. Rapport á M. le Ministre de l'Éducation Nationale, 2002. http://www.education.gouv.fr/rapport/ debray/default.htm, capturado em $1 \stackrel{\circ}{\circ} / 8 / 2004$.

FERRARI, Silvio. "Separation of Church and State in Contemporary European Society". Journal of Church and State, 30 (3), 1988: 533-47.

FISCHMANN, Roseli. "Escolas públicas e ensino religioso: subsídios para a reflexão sobre o Estado laico, a escola pública e a proteção do direito à liberdade de crença e de culto". Comciência - revista digital, n. 56, julho de 2004. http://www.comciencia.br, capturado em 10/7/2004.

GIUMBELLI, Emerson. O fim da religião: dilemas da liberdade religiosa no Brasil e na França. São Paulo, Attar/Pronex, 2002.

HERVIEU-LÉGER, Danièle. Le Pèlerin et le Converti. La religion en mouvement. Paris, Flammarion, 1999.

JUNQUEIRA, Sérgio Rogério Azevedo. O processo de escolarização do Ensino Religioso no Brasil. Petrópolis, Vozes, 2002.

MINC, Carlos. "Educação religiosa e ensino público". O Globo, 9/10/2000.

OZOUf, Mona. L'École, l'Église et la Republique. Paris, Seuil, 1982.

POULAT, Émile. Liberté, Lä̈cité: la guerre de deux France et le principe de la modernité. Paris, CERF/Cujas, 1987.

VÁRIOS AUTORES. Nouveaux enjeux de la laïcité. Paris, Centurion, 1990.

VIANA, Daniela; BELLOTTI, Karina e BASSINI, Marili. "Ensino religioso na rede pública do Estado de São Paulo: desafios e perspectivas". Texto disponível na "Biblioteca Digital” da "Comunidade Virtual do Ensino Religioso". http://www.ensinoreligioso.com.br, capturado em 13/7/2004.

RESUMO - O ARTIGO propõe uma discussão sobre Estado e religião considerando alguns ideais relacionados à modernidade. Fazendo a laicidade parte desses ideais, o foco é colocado sobre a relação entre religião e escola. São analisados diversos textos que se interessam por essa relação e que se envolvem com definições jurídicas e iniciativas governamentais, procurando-se um contraponto entre as situações na França e no Bra- 
sil. Da França, escolheu-se dois relatórios encomendados pelo governo, o da Comissão sobre a Laicidade (2003) e o do "ensino do fato religioso" na escola (2002). Do Brasil, privilegiou-se quatro intervenções sobre os rumos que vêm tomando a discussão acerca do ensino religioso nas escolas públicas nos Estados do Rio de Janeiro e de São Paulo.

ABSTRACT - THIS ESSAY proposes a discussion about religion and the State, taking into consideration certain ideals related to Modernity. Inasmuch as laicization is part of these ideals, the focus is on the relationship between religion and the school. Several texts dealing with this relationship, with judicial definitions and with governmental initiatives are analyzed, in an attempt to establish a counterpoint between the situation in France and in Brazil. From France, we examine two reports commissioned by the government - one from the Commission on Laicity (2003) and one on the "teaching of religious facts" in schools (2002). From Brazil, we peruse four interventions on the trends of the debate on religious teaching in public schools in the states of Rio de Janeiro and São Paulo.

Emerson Giumbelli é professor do Departamento de Antropologia Cultural da Universidade Federal do Rio de Janeiro (UFRJ) e integrante do Programa de Pós-Graduação em Sociologia e Antropologia, também da UFRJ.

Texto recebido e aceito para publicação em 24 de setembro de 2004. 